\title{
Cumulative Index for 2013; Vol 159
}

\section{A-B}

A brief history of British military experiences with infectious and tropical diseases M S Bailey ....... 150 A comparison of two 3 -week resistance training programmes commonly used in short-term military rehabilitation J Kristensen, $S$ Burgess. . . . . . . . 35 A massive occult pericardial effusion in an athletic young male MH Thompson, $G D$ Corbett, A Cherian, E D Nicol. . . . . . . . . . . . . . . . . . . 126

Acute hepatitis A virus infections in British Gurkha soldiers C A Green, D A Ross, M S Bailey . . . . . . . 240 An unusual case of anaemia and lymphadenopathy in a soldier on deployment $M K$ O'Shea, $R$ Gregg, J Naylor . . . . . . . . . . . . . . . . . . . 243 Anorectal injury in pelvic blast $T G$ Brogden, J P Garner. . . . . . . . . . . . . . . . . . . i 26 Balkans syndrome: a potential link between multiple sclerosis and hypervaccination $R$ C Firth, D Ross .... 59 Behavioural activation for the treatment of depression in military personnel $D$ Whybrow ............. 15

\section{C-D}

Candida tropicalis: diagnostic dilemmas for an unusual prosthetic hip infection S Lidder, A Tasleem, S Masterson, $R$ W J Carrington. . . . . . . . . . . . . . . . 123 Complex lower genitourinary reconstruction following combat-related injury $L$ Uppal, $P$ Anderson, D Evriviades . . . . . . . . . . . . . . . . . . . . . i49 Controversies in the management of salivary gland disease M J Breeze . . . . . . . . . . . . . . . . . . . . 129 Deployed antimicrobial stewardship: an audit of antimicrobial use at Role $3 T$ E Fletcher, E Hutley, C J Adcock, N Martin, D R Wilson . . . . . . . . . 237 Developing a cumulative anatomic scoring system for military perineal and pelvic blast injuries $S$ Mossadegh, M Midwinter, P Parker . . . . . . . . . . . . . . . i 40 Diagnosis, management and operational impact of panic disorder in the UK Armed Forces F E Smith, R H Coetzee .......................440 Dynamic pressure testing for chronic exertional compartment syndrome in the UK military population $S$ Dharm-Datta, D F Minden, P A Rosell, P F Hill, A Mistlin, J Etherington . . . . . . . . . . . . . . 114

\section{E-F}

Energy expenditure and changes in body composition during exercise-based rehabilitation J Kristensen . . . . 30 Enteric disease on Operation HERRICK $P$ Connor, E Hutley, H E Mulcahy, M S Riddle . . . . . . . . . . 229

\section{G-H}

Hepatitis B and C in the Armed Forces D A Freshwater ... . . . . . . . . . . . . . . . . 169 Hepatitis E: the forgotten virus D A Freshwater . . . 167
I-J

Immediate surgical management of combat-related injury to the external genitalia D M Sharma, D M Bowley. . . i18 Infectious disease control in the Ionian Islands during the British Protection (1851-1864) C Tsiamis, E Thalassinou, E Poulakou-Rebelakou, D Anogiatis-Pelé, A Hatzakis . 247

K-L

Lifeline: a British casualty clearing station on the Western Front, 1918 R G Simpson . . . . . . . . . . . . . . 130

\section{M-N}

Major General Henry Douglas VC RAMC: his military and non-military accomplishments $M$ Duke . . . . 131 Malaria T E Fletcher, NJ Beeching. . . . . . . . . . 158 Managing endocrine dysfunction following blast injury to the male external genitalia $D R$ Woods, $R$ Phillip, $R$ Quinton........................ 445 Medical lessons learnt from the US and Canadian experience of treating combat casualties from Afghanistan and Iraq S Dharm-Datta, J McLenaghan......... 102 Medical provision in forward locations in Afghanistan: the experiences of General Duties Medical Officers on Op HERRICK 15 A E Gumbley, M A Claydon, T N Blankenstein, $T$ H Fell . . . . . . . . . . . . . 68 Military nephrology: magnitude of rates of deterioration in renal function $M J$ World . . . . . . . . . . . 98 Military treatment of splenic injury in the era of non-operative management $S$ Mossadegh, M Midwinter, W Sapsford, N Tai . . . . . . . . . . . . . . . . . . 110 Modelling for conflict: the legacy of ballistic research and current extremity in vivo modelling W $G$ P Eardley, S A Watts, J C Clasper . . . . . . . . . . . . . . . 73

\section{O-P}

On two hundred years of Director Generals A MacMillan 4 Operational medical force protection: the collective solution C D Bonser, J R Fawcett . . . . . . . . . . 51 Pelvic fracture-related urethral and bladder injury J J Durrant, A Ramasamy, M S Salmon, N Watkin, I Sargeant . . . ................. i32 Perforation of fragment simulating projectiles into goat skin and muscle J Breeze, G R James, A E Hepper . . . . 84 Post-operative negative pressure pulmonary oedema in an athletic male $S$ K Stewart, A McD Johnston. . . . . . 56

\section{Q-R}

Radial forearm flaps as durable soft tissue coverage for local nationals being treated in the field hospital setting K H Hanna, S L A Jeffery. . . . . . . . . . . . . . . 21 
Rapid intelligence and failing weapons: meeting the challenges of 21st century infections in the deployed clinical environment E J Hutley, A S M Matheson, J Biswas, A D Green. . . . . . . . . . . . . . . . . . 144 Renal function after trauma $M J$ World. . . . . . . . 94 Respiratory infections in the military $M K$ O'Shea, DWilson....................... 181 Review of cases of IgA nephropathy M J World. . . . 90 Round Afghanistan with a fridge $G$ Wild, D Anderson, $P$ Lund . . . . . . . . . . . . . . . . . . . . . 24

\section{S-T}

Sepsis management in the deployed field hospital A McD Johnston, D Easby, I Ewington . . . . . . . . 175 Sexual health and HIV in the Army N E Dufty, K Clay, $R$ Wilson, J Watson. . . . . . . . . . . . . . . 206 Skin and soft tissue infections in the military L Lamb, M Morgan. . . . . . . . . . . . . . . . . . . 215 Smoking prevalence amongst UK Armed Forces recruits: changes in behaviour after 3 years follow-up and factors affecting smoking behaviour I Bray, $P$ Richardson, $K$ Harrison . . . . . . . . . . . . . . . . . . . . 44 Technical tip: removal of tungsten carbide rings S McCarver, S L A Jeffery. . . . . . . . . . . . . 64 The (changing) nature of this beast J $P$ Garner . . . . . 2 The development and introduction of ballistic protection of the external genitalia and perineum $E A$ Lewis, M A Pigott, A Randall, A E Hepper. . . . . . . . . . . . i15 The management of genitourinary war injuries: a multidisciplinary consensus D M Sharma, on behalf of the Genitourinary Working Group (Trauma) . . . . . . . . i i57
The physical basis of explosion and blast injury processes W G Proud . . . . . . . . . . . . . . . . . . . . i4 The psychological challenge of genital injury W Frappell-Cooke, P Wink, A Wood . . . . . . . . . . i 52 The role of diagnostic CT imaging in the acute assessment of battlefield external genital injuries $R P M$ Rushambuza ..................... 21 The safety and efficacy, and recommendations for the use of biologic drugs in the UK military rheumatology population A N Bennett, A D Green, J Rees, T Jones, D Harris,

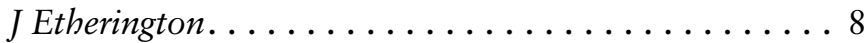
The surgical anatomy of the perineum $V$ Mahadevan, $P$ Chandak ......................... 110 Trauma treatment in a Role 1 medical facility in Afghanistan P N Vedel, I Helsø, H L Jørgensen, J Bruun

Lauritzen, L Ravnborg Nissen . . . . . . . . . . . . . 119 Tropical skin diseases in British military personnel M S Bailey. . . . . . . . . . . . . . . . . . . 224 Tuberculosis and the military M K O'Shea, D Wilson. 190

\section{U-V}

UK Role 4 Military Infection Services: past, present and future N E Dufty, M S Bailey. . . . . . . . . . . . . 141 Undifferentiated febrile illnesses in military personnel D S Burns, M S Bailey . . . . . . . . . . . . . . . 200 Update on military diarrhoea: current status and future plans P Connor, R L Gutierrez . . . . . . . . . . . 136

\section{W-X}

Walcheren 1809 J Clasper . . . . . . . . . . . . . . 61 Why isn't everyone doing research? L M M Bernthal . 66 WB12 Wound Ballistics Symposium D Carr . . . . . . 62 